\title{
Possibilities for Reducing CO and TOC Emissions in Thermal Waste Treatment Plants: A Case Study
}

\author{
Janusz Bujak $^{1, *}$, Piotr Sitarz ${ }^{2}$ and Rafał Pasela ${ }^{1}$ \\ 1 Faculty of Environmental Engineering, University of Science and Technology in Bydgoszcz, Kaliskiego 7, \\ 85-796 Bydgoszcz, Poland; rafal.pasela@utp.edu.pl \\ 2 PPM PROMONT Bujak Sp. z o.o.-Sp. K., Bydgoszcz, Jagiellońska 35, 85-097 Bydgoszcz, Poland; \\ p.sitarz@promont.com \\ * Correspondence: janusz.bujak@utp.edu.pl or j.bujak@promont.com; Tel.: +48-501-541185; \\ Fax: +48-523-220853
}

check for updates

Citation: Bujak, J.; Sitarz, P.; Pasela, R. Possibilities for Reducing CO and TOC Emissions in Thermal Waste Treatment Plants: A Case Study. Energies 2021, 14, 2901. https:// doi.org/10.3390/en14102901

Received: 16 April 2021

Accepted: 14 May 2021

Published: 17 May 2021

Publisher's Note: MDPI stays neutral with regard to jurisdictional claims in published maps and institutional affiliations.

Copyright: (c) 2021 by the authors. Licensee MDPI, Basel, Switzerland. This article is an open access article distributed under the terms and conditions of the Creative Commons Attribution (CC BY) license (https:/ / creativecommons.org/licenses/by/ $4.0 /)$.

\begin{abstract}
The technology of waste-management thermal processing may pose a threat to the natural environment through the emission of harmful substances, such as $\mathrm{CO}, \mathrm{NOx}, \mathrm{SO}_{2}, \mathrm{HCl}, \mathrm{HF}$, total organic carbon (TOC) and dust, as well as dioxins and furans. Due to the advantages of thermal waste treatment, including the small volume of solid residue produced and possible thermal energy recovery, thermal waste treatment is widely applied. Continuous research is necessary to develop methods for reducing the risk of harmful substances being produced and methods for the effective removal of pollutants resulting from flue gases. This paper presents an analysis of the results and conditions of the experimental redesign of a thermal industrial waste (polypropylene) treatment plant. The purpose of the redesign was to improve the quality of gasification and afterburning processes taking place in the combustion and afterburner chambers (through the installation of an additional section), thus resulting in a reduction in the concentrations of $\mathrm{CO}$ and total organic carbon (TOC) in flue gases. The research concerned a facility implementing the combustion process on an industrial scale. The experiment led to a reduction in the average concentrations of carbon monoxide from $16.58 \mathrm{mg} / \mathrm{m}^{3}$ to $3.23 \mathrm{mg} / \mathrm{m}^{3}$ and of volatile organic compounds from $2.20 \mathrm{mg} / \mathrm{m}^{3}$ to $0.99 \mathrm{mg} / \mathrm{m}^{3}$. At the same time, no deterioration was observed in any of the remaining technological parameters of the plant, such as waste combustion performance and the energy efficiency of the thermal energy recovery system.
\end{abstract}

Keywords: waste thermal treatment; flue gas treatment; air pollution; rotary kiln

\section{Introduction}

Thermal treatment is a basic method for the protection and management of different types of waste. It is characterized by its production of a relatively small volume of solid residues (ash) and by the possible recovery of otherwise wasted thermal energy. This technology, however, may pose a threat to the natural environment through the emission of harmful substances and compounds. Therefore, it is necessary to carry out research on methods and design solutions aimed at reducing the above hazards. Additionally, strict regulatory restrictions have been introduced, and best available techniques (BAT) have been promoted, within the European Union to enforce the appropriate quality of waste treatment processes [1-3].

A review of the literature shows that intense research on methods for limiting the emission of pollutants into the natural environment has been conducted all over the world. Some papers concentrated on an analysis of hazards and a reduction in emissions for small-scale waste treatment facilities [4,5]. Various studies on large-scale facilities have also been conducted [6,7]. This includes, for example, plants intended to treat food-industry waste [8-11] and hospital waste [12-14]. In some studies, models of the interdependence between combustion-process emission parameters and other important factors, such as 
waste-to-energy, were highlighted and presented [15-20]. Examples of methods for reducing the emission of harmful compounds are included in the articles [21-23].

This article presents an analysis of a case in which the emission of harmful substances, such as total organic carbon (TOC) and carbon monoxide (CO), was reduced in a thermal industrial waste treatment plant. When cleaning flue gases, primary methods (preventing the generation of flue gases) and secondary methods (involving the removal of pollutants resulting from flue gases) are applied. The theoretical basis and the characteristics of methods employed in the tested facility are shown in Section 2.

The aim of the modernization was to reduce the average daily concentration of $\mathrm{CO}$ and TOC as much as possible. The legal regulations indicate the maximum permissible average daily concentrations for these substances $\left(50 \mathrm{mg} / \mathrm{m}^{3}\right.$ for $\mathrm{CO}$ and $10 \mathrm{mg} / \mathrm{m}^{3}$ for TOC). If these levels are exceeded, loading into the installation is stopped, and a financial penalty is charged. There is also a fee for environmental pollution resulting from the amount of emitted harmful substances. It is advisable to search for design solutions that limit the probability of emission of these harmful compounds to the environment.

An improvement in the flue-gas-afterburning process efficiency (primary method) was verified in the described research. This process takes place in the afterburner chamber. The primary technological factors affecting the quality of that process are the residence time of flue gases in the afterburner chamber, the temperature and the chamber shape.

This research was conducted in a facility implementing the combustion process on an industrial scale. The analyzed thermal waste treatment unit was located on the premises of an industrial plant with technological lines for manufacturing polypropylene film tapes. With an incineration plant located next to the facility, it is possible to efficiently use the production and external waste to obtain thermal energy for heating the thermal oil used in the production process. The tested thermal waste treatment plant consists of the following components: a waste-loading section; a rotary kiln for preliminary waste gasification; an afterburner chamber (thermal reactor); a NOx reduction unit (urea dosing); a thermal energy recovery section (thermal oil boilers); $\mathrm{SO}_{2}, \mathrm{HCl}$, and $\mathrm{HF}$ (sorbent dosing) reduction units; a cloth filter for removing solid particles from flue gases; and a continuous flue-gas monitoring unit installed on the funnel.

The tested installation was rebuilt, the rotary combustion chamber was enlarged, and an additional section for the afterburning chamber was installed (Figure 1). In order to evaluate the efficiency of the applied solution, a comparative statistical analysis was carried out for two periods (about 60 days) before and after the modernization. The technological parameters of operation of the incineration plant and the concentration of pollutants in the flue gases emitted to the atmosphere were recorded during these periods.

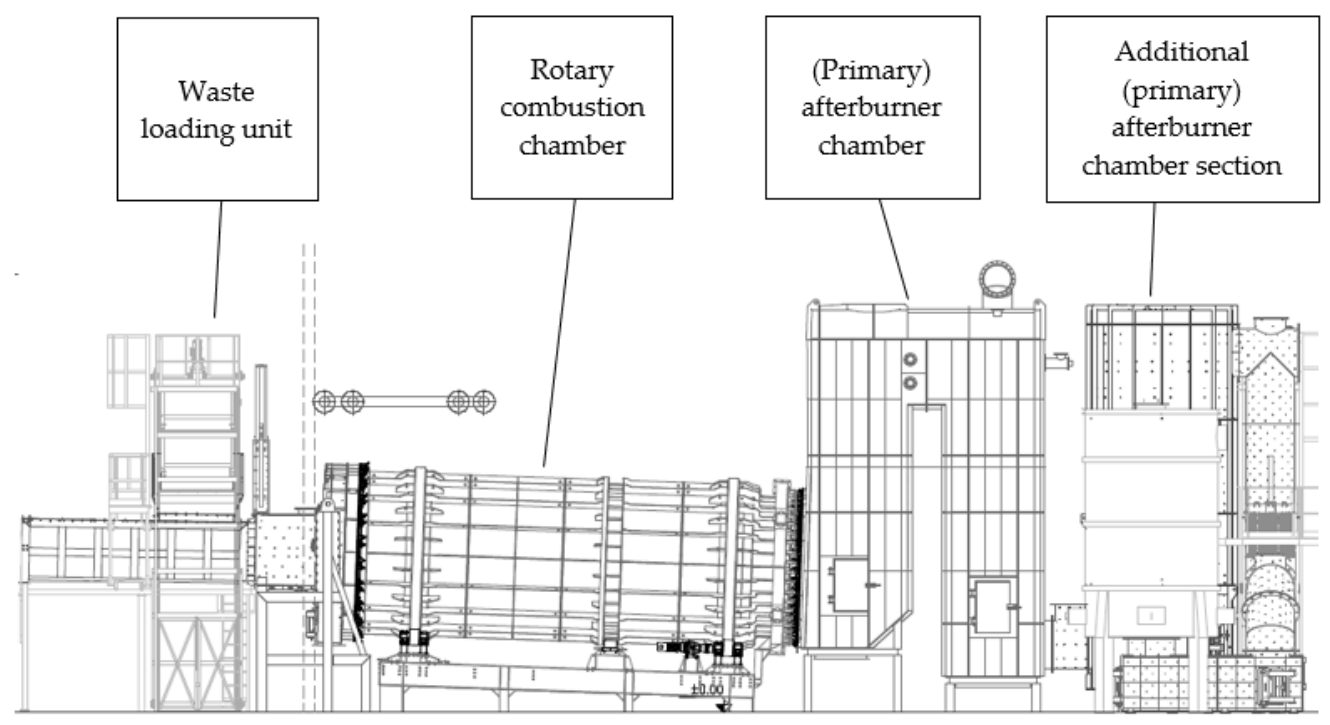

Figure 1. Rotary combustion chamber and afterburner chamber with additional section. 


\section{Possibilities for Reducing Emissions of Harmful Substances}

\subsection{Loading Waste}

A method used for reducing the risk of harmful substances being generated during waste incineration is the automatic control of loading through a programmable logic controller (PLC). In the process of loading, waste is delivered to the loading chamber of the rotary kiln using a lift. Then, it is moved into the combustion chamber using a hydraulic piston. The waste is loaded on a cyclical basis. The mean loading frequency is approximately $15 \mathrm{~min}$, while the average weight of one load is $50 \mathrm{~kg}$.

The automatic control system limits the emission of dust and carbon monoxide by blocking the loading operation under the following conditions:

- During start-up, when the required temperatures in the rotary kiln and the afterburner chamber are too low;

- During operation, when the required temperatures exceed the maximum values or when the permissible amounts of pollutants emitted into the air are exceeded;

- When the proper loading cycle is not maintained;

- When the excessive weight of a single load causes an intensification of the combustion process in the initial part of the rotary kiln, resulting in a periodic drop in $\mathrm{O}_{2}$ content in the rotary kiln and the afterburner chamber. On the other hand, too much waste falling on the incinerated layer results in it being heavily disturbed, which leads to the emission of excessive amounts of volatile dust.

\subsection{Rotary Kiln}

The generation of harmful substances during waste treatment in the rotary chamber is limited by controlling this process through an automatic control system. Fed material is decomposed into solid and gaseous products in the rotary kiln. The rotary chamber is equipped with a gas burner. It serves to heat the kiln during start-up and to maintain temperature in the kiln during the operation of the plant. A negative pressure of approximately $80 \mathrm{~Pa}$ is maintained inside the rotary kiln during the process of thermal waste treatment.

The automatic rotary kiln control unit ensures that the generation of harmful substances is limited by the following steps:

- Smooth adjustment of the rotational speed (in the range of 1 to 10 revolutions per hour) and cyclic/periodic operation. The rotational speed setting determines the efficiency of the plant and the level of combustion slag burnout. It also affects the emission of volatile dust and carbon monoxide;

- Adjustment of negative pressure in the chamber to ensure proper air inflow and maintain a proper excess of oxygen (CO generation limitation).

\subsection{Afterburner Chamber}

The (primary) methods used for limiting the risk of harmful substances being generated are also applied when controlling the operation of the afterburner chamber. Gaseous products generated in the combustion chamber are fed to the afterburner chamber. In the afterburner chamber, organic substances are thermally destroyed at high temperature and oxidized to final combustion products. The size of the chamber guarantees the appropriate residence time of flue gases (above $2 \mathrm{~s}$ ) and their proper temperature (above $1100{ }^{\circ} \mathrm{C}$ ). The temperature in the afterburner chamber is adjusted automatically with a modulated gas burner or additional air. The emergency funnel is an integral part of the afterburner chamber. The afterburner chamber is also equipped with an automatic unit for removing combustion ashes.

The automatic control system of parameters in the afterburner chamber ensures that the generation of harmful substances is minimized through the following steps:

- Maintaining an adequate flow rate of flue gases at given dimensions of the chamber to ensure the appropriate residence time of flue gases (minimum of $2 \mathrm{~s}$ ); 
- Controlling the operation of the gas burners and the amount of additional air supplied to the afterburner chamber to maintain the required temperature (above $1100{ }^{\circ} \mathrm{C}$ );

- Controlling (limiting) the amount of additional air supplied to the afterburner chamber in order to avoid NOx synthesis;

- Controlling the temperature and residence time of flue gases in the chamber to ensure the thermal decomposition of dioxins and furans. An optimal excess of oxygen in flue gases $(8-9 \%)$ substantially helps to reduce the emission of carbon monoxide and volatile organic substances.

\subsection{Urea Dosing Unit}

In cases wherein NOx is generated during the incineration of waste, it is necessary to employ a proper method for its removal from the flue-gas stream. For this purpose, a urea-dosing unit is used. It was designed for the so-called selective noncatalytic reduction of NOx (SNCR). It works by injecting a urea/water solution directly into the zone of flowing flue gases. The proper location of the urea injection point is essential for the effective reduction of NOx. The NOx reduction process is most efficient in a relatively narrow temperature range, the so-called "temperature window", from 920 to $1050^{\circ} \mathrm{C}$.

\subsection{Recovery Boilers}

The limitation of the generation of harmful substances during the flow of flue gases through the recovery boilers is ensured by an automatic control system (flow rate control). After leaving the afterburner chamber, flue gases at $1100-1200{ }^{\circ} \mathrm{C}$ flow through the boilers to heat the thermal oil used in the production process. The flue gases dissipating heat are cooled to $220^{\circ} \mathrm{C}$. The heat transfer surface of the recovery boiler is $\mathrm{F}=220 \mathrm{~m}^{2}$, guaranteeing the fast cooling of flue gases, which limits the reemission of dioxins and furans (so-called "de novo" synthesis).

\subsection{Unit for Dosing Sorbent into Flue Gases}

Flue gases are cleaned of harmful compounds after the recovery boilers by the sorbent dosing unit. After leaving the recovery boiler, the flue gases are moistened before being subjected to stream adsorption. This involves a direct dry injection of a highly efficient reagent into the flue-gas stream. The basic components of the sorbent are calcium hydroxide and powdered activated carbon. Stream adsorption in combination with a cloth filter made from Teflon membranes is a very effective method for removing dioxins, furans, acidic gas pollutants, volatile dust and heavy metals.

\subsection{Bag Filter}

The flue-gas stream entering the initial chamber is expanded in a bag filter, leading to coarser and heavier dust fractions being separated. The uniform distribution of the flue gas stream in the whole chamber causes the dust to settle on the outer surface of the filter bags. Cleaned gas flows into the bag before being moved to the outlet manifold. The dust retained on the bags, together with the used sorbent, is periodically shaken off by short pulses of compressed air supplied into the bag. The dust collected in the hoppers under the filter sections is transported to a container by means of a screw conveyor. The filter cleaning process is controlled by a microprocessor controller with a preset frequency in the event that the assumed flue gas flow resistance is exceeded.

\section{Description of the Flue-Gas Parameter Measuring Unit}

\subsection{Methods for Measuring Concentrations of Harmful Substances}

Empirical data on the concentration of harmful substances were collected with a continuous flue-gas monitoring system consisting of a set of analyzers and a computer recording system. Such systems are obligatorily installed in thermal waste treatment installations. Continuous measurement and the registration of measured values allows for the creation of reports required by environmental protection services in accordance with 
applicable legal acts. A computer with a database is used to collect, process, report and archive information on concentrations and emissions of harmful substances. The system must meet the requirements of current legal regulations in the field of data processing systems for continuous emission measurements and is subject to inspection procedures. The system was completed and delivered by Envag [24].

An extraction method for measuring the concentrations of harmful substances in flue gases was applied in the tested facility (the measuring path and analyzers were heated), whereas the flow rate, pressure and temperature of flue gases and the dust level were directly measured in the flue-gas duct. A sample taken from the funnel (by means of a stainless-steel test tube) was prefiltered through a heated ceramic filter installed in the measuring probe. The sample was transferred through a heated hose into a room with a measuring cabinet containing a sample preparation unit and a set of analyzers. Both before and after the modernization, gas samples were taken from the chimney discharging the fumes to the atmosphere.

Parameters measured by the continuous flue-gas monitoring system and their metrological qualities are shown in Table 1.

Table 1. Values measured by the continuous flue-gas monitoring system, along with their measuring ranges and measurement errors.

\begin{tabular}{|c|c|c|c|}
\hline Measured Parameters & Measuring Device & Measuring Range & Measurement Error (\%) \\
\hline Total dust, $\mathrm{mg} / \mathrm{m}^{3}$ & D-RX 250 & $0-10$ & 2.0 \\
\hline Total organic carbon, $\mathrm{mg} / \mathrm{m}^{3}$ & JUM 3-700 & $0-160$ & 1.0 \\
\hline Hydrogen chloride, $\mathrm{mg} / \mathrm{m}^{3}$ & CX-4000 & $0-50$ & 2.0 \\
\hline Hydrogen fluoride, $\mathrm{mg} / \mathrm{m}^{3}$ & CX-4000 & $0-10$ & 2.0 \\
\hline Sulfur dioxide, $\mathrm{mg} / \mathrm{m}^{3}$ & CX-4000 & $0-2000$ & 2.0 \\
\hline Carbon monoxide, $\mathrm{mg} / \mathrm{m}^{3}$ & CX-4000 & $0-700$ & 2.0 \\
\hline Nitrogen monoxide, $\mathrm{mg} / \mathrm{m}^{3}$ & CX-4000 & $0-1000$ & 2.0 \\
\hline Carbon dioxide, $\%$ & CX-4000 & $0-20$ & 2.0 \\
\hline Oxygen, $\%$ & AMS-3220 & $0-25$ & 2.0 \\
\hline Humidity, \% & $C X-4000$ & $0-30$ & 2.0 \\
\hline Flue-gas stream, $\mathrm{m}^{3} / \mathrm{h}$ & $\mathrm{D}-\mathrm{R} \times 250$ & $0-10,000$ & 2.0 \\
\hline Flue-gas temperature, ${ }^{\circ} \mathrm{C}$ & $\mathrm{D}-\mathrm{R} \times 250$ & $0-200$ & 2.0 \\
\hline Static pressure, mbar & $\mathrm{D}-\mathrm{R} X 250$ & $0-1600$ & 0.25 \\
\hline
\end{tabular}

\subsection{Analysers}

The following analyzers were used during the tests: the CX-4000, AMS-3220 and JUM model 3-700.

The CX-4000 is an analyzer that uses the Fourier-transform infrared (FT-IR) measuring method, which is based on the ability of multiatomic gas molecules to absorb infrared radiation. This method makes it possible to determine almost all compounds using a single analyzer. In addition to $\mathrm{CO}, \mathrm{CO}_{2}, \mathrm{NO}_{2}, \mathrm{NO}, \mathrm{N}_{2} \mathrm{O}, \mathrm{SO}_{2}, \mathrm{HF}, \mathrm{HCl}$, and steam $\left(\mathrm{H}_{2} \mathrm{O}\right)$ were identified.

The AMS-3220 was used to measure the concentration of oxygen in flue gases. It includes a zirconium sensor with a flow control module and an electronic unit for controlling the sensor, processing and recording a signal. The zirconium sensor is mounted in such a way that the flue-gas sample flows through the measuring part, while the reference part remains in contact with ambient air.

The JUM model 3-700 was used to measure the total organic compounds (TOCs). It applies the method of continuous flame ionization detection (FID). In this method, molecules of hydrocarbons from the sample gas are ionized in the flame region.

The assemblies of all analyzers were protected against water condensation using an automatic air-blowing unit. A computer was installed in the measuring cabinet to analyze the data sent from the analyzers and the conditioning system. 


\subsection{Measurements of Flow, Dust Concentration, and Flue Gas Temperature and Pressure}

An integrated D-RX 250 probe was used to measure the flow rate, temperature and pressure of flue gases and the concentrations of dust. The probe measured the following parameters with the following techniques:

- $\quad$ The flow of flue gases, using the differential pressure method;

- The concentrations of dust, by determining the charge carried by dust molecules using the triboelectric method;

- The temperature of flue gases, using a resistance sensor;

- Flue-gas pressure.

\section{Set Objectives of the Modernization}

The modernization of the thermal waste treatment plant, some effects of which are discussed in this paper, was carried out in order to increase efficiency and reduce the emission of harmful substances into the atmosphere. Previously, emissions of pollutants in the incineration plant did not exceed the permissible levels (Regulation [1]. However, during the scheduled redesign, modifications were considered to improve the result obtained in this respect.

The efficiency of methods used for minimizing the risk of harmful compounds (described in Section 2) depends largely on the structural solutions of the incinerator and its parameters. For example, the shape and dimensions of the combustion chamber are important. It is essential to provide a sufficient residence time for flue gases in the chamber to increase the probability of afterburning carbon compounds to $\mathrm{CO}_{2}$. Another important step is to ensure a circular motion of the flue gas stream owing to the proper shape of the afterburner chamber. The modernization consisted of an increase in the afterburner chamber volume from $64 \mathrm{~m}^{3}$ to $96 \mathrm{~m}^{3}$ by installing an additional section.

\section{Results of the Study}

The aim of the study was to validate the average level of concentrations of harmful substances in flue gases in two periods, i.e., before and after the modernization. The results were statistically verified by testing the difference between the values expected from two populations (with large samples). The null hypothesis, which assumed equality of the means of the said populations (concentrations of pollutants before and after the modernization of the incineration plant) was rejected when the test statistic $\mathbf{u}$ took values from the critical area $R_{\alpha}:\left(-\infty ;-u_{\alpha / 2}\right)$ and $\left(u_{\alpha / 2} ; \infty\right)$. For a two-sided test, this value was calculated as $u_{\alpha / 2}=1.96$.

$$
u=\frac{\bar{x}_{1}-\bar{x}_{2}}{\sqrt{\frac{\sigma_{1}^{2}}{n_{1}}+\frac{\sigma_{2}^{2}}{n_{2}}}}
$$

where: $x_{1}$ is the average concentration in the sample before the modernization, $x_{2}$ is the average concentration in the sample after the modernization, $\sigma_{1}$ is the standard deviation of the population before the modernization, $\sigma_{2}$ is the standard deviation of the population after the modernization, $n_{1}$ is the sample size before the modernization, and $n_{2}$ is the sample size after the modernization.

For example, in the case of carbon monoxide, the measured average value was $16.58 \mathrm{mg} / \mathrm{m}^{3}$ before the modernization and $3.23 \mathrm{mg} / \mathrm{m}^{3}$ after the redesign (Figure 2). The value of the test statistic $u=8.10$ refers to the right-sided critical area $R_{\alpha}:(-\infty ;-1.96)$ and $(1.96 ; \infty)$. The null hypothesis, which assumed the equality of the means of the populations being tested (concentrations of pollutants before and after the modernization of the incineration plant), was rejected. There was an alternative hypothesis assumed, according to which the $\mathrm{CO}$ concentration was higher before the modernization. One can state that the modernization caused a statistically significant change in $\mathrm{CO}$ concentration in the flue gases (there was a decrease in the concentration). 

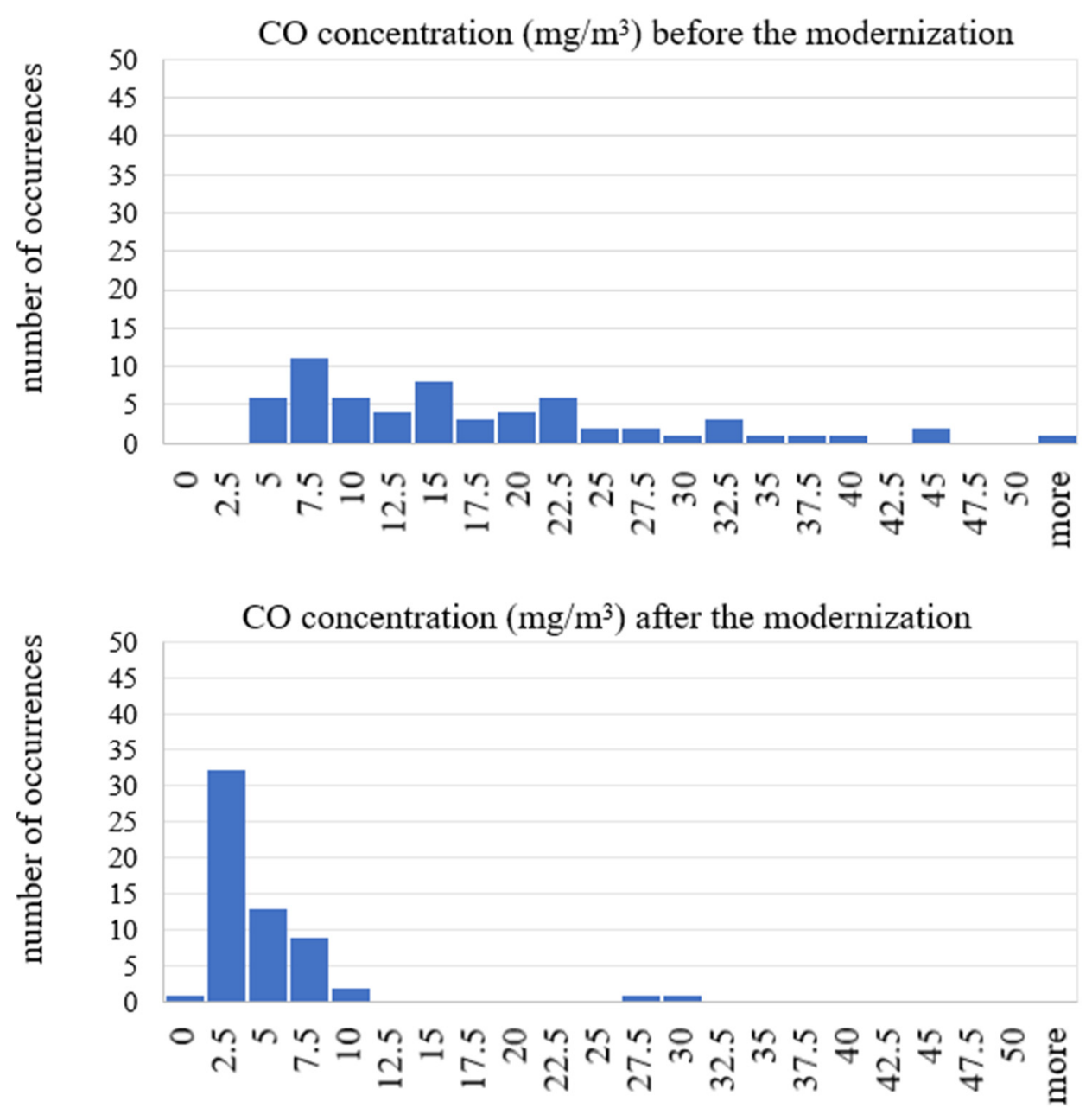

Figure 2. Comparison of average daily histograms of $\mathrm{CO}$ concentrations before and after the modernization.

The aggregated results of the tests of concentrations of harmful substances and the maintained technological parameters are given in Table 2. Data were recorded at $1 \mathrm{~min}$ intervals. Based on these data, 62 daily averages were obtained in the study period before modernization and 59 daily averages in the period after improvement.

The set operating parameters of the installation were the same in both these periods. The flue-gas temperature in the afterburning chamber should not be lower than 1100 ${ }^{\circ} \mathrm{C}$ (for waste containing more than $1 \%$ chlorine). Average concentrations of harmful substances calculated for $30 \mathrm{~min}$ and $24 \mathrm{~h}$ periods should not exceed the levels indicated in the regulation [1]. These concentrations are converted to a reference $\mathrm{O}_{2}$ concentration of $11 \%$. The rotational speed of the combustion chamber in both periods was not changed and was 3.5 revolutions per hour.

During the research period, the following average operating parameters of the waste incineration plant were maintained. The flue-gas volume flow was $4248 \mathrm{~m}^{3} / \mathrm{h}$. The $\mathrm{O}_{2}$ concentration in the exhaust gas was $10.8 \%$. The water content in the exhaust gas was $7.8 \%$. The flue-gas temperature was $1101{ }^{\circ} \mathrm{C}$ before the thermal oil boilers and $326{ }^{\circ} \mathrm{C}$ after the boilers. The energy stream of the supplied waste was $1681 \mathrm{~kW}$, while the thermal energy stream of the thermal oil reached $1154 \mathrm{~kW}$. The temperature of the thermal oil at the outlet from the installation was $278{ }^{\circ} \mathrm{C}$ and $243^{\circ} \mathrm{C}$ on the return.

An analysis of the above results indicates that the modernization of the system caused a decrease in the average daily concentrations of harmful substances, including carbon monoxide (Figure 2), volatile organic compounds (Figure 3), and dust. The decrease in dust concentration resulted from the increased turbulence of the flue-gas stream at the 
transition from the first afterburner chamber to its additional section and the extended total flue-gas retention time.

Table 2. Test of the difference in expected values of the two populations.

\begin{tabular}{|c|c|c|c|c|c|}
\hline $\begin{array}{l}\text { Tested Parameter } \\
\text { (Average } 24 \mathrm{~h} \text { ) }\end{array}$ & Unit & $\begin{array}{l}\text { Average Value } \\
\text { before the } \\
\text { Modernization }\end{array}$ & $\begin{array}{l}\text { Average Value } \\
\text { after the } \\
\text { Modernization }\end{array}$ & $u$ & $\begin{array}{l}\text { Result of the } \\
\text { Modernization }\end{array}$ \\
\hline CO concentration & $\mathrm{mg} / \mathrm{m}^{3}$ & 16.58 & 3.23 & 8.10 & Decrease \\
\hline TOC concentration & $\mathrm{mg} / \mathrm{m}^{3}$ & 2.20 & 0.99 & 1.97 & Decrease \\
\hline Dust concentration & $\mathrm{mg} / \mathrm{m}^{3}$ & 0.862 & 0.679 & 5.33 & Decrease \\
\hline NOx concentration & $\mathrm{mg} / \mathrm{m}^{3}$ & 41.41 & 52.36 & -5.10 & Increase \\
\hline $\mathrm{SO}_{2}$ concentration & $\mathrm{mg} / \mathrm{m}^{3}$ & 7.60 & 8.73 & -1.53 & No change \\
\hline $\mathrm{HCl}$ concentration & $\mathrm{mg} / \mathrm{m}^{3}$ & 4.27 & 4.02 & 0.39 & No change \\
\hline HF concentration & $\mathrm{mg} / \mathrm{m}^{3}$ & 0.150 & 0.002 & 1.55 & No change \\
\hline $\begin{array}{l}\text { Residence time in the } \\
\text { afterburner chamber }\end{array}$ & $\mathrm{s}$ & 13.69 & 15.46 & -4.17 & Increase \\
\hline $\mathrm{O}_{2}$ concentration & $\%$ & 13.84 & 13.56 & 1.35 & No change \\
\hline $\begin{array}{l}\text { Temperature in the } \\
\text { afterburner chamber }\end{array}$ & ${ }^{\circ} \mathrm{C}$ & 1112.9 & 1125.2 & -0.84 & No change \\
\hline
\end{tabular}
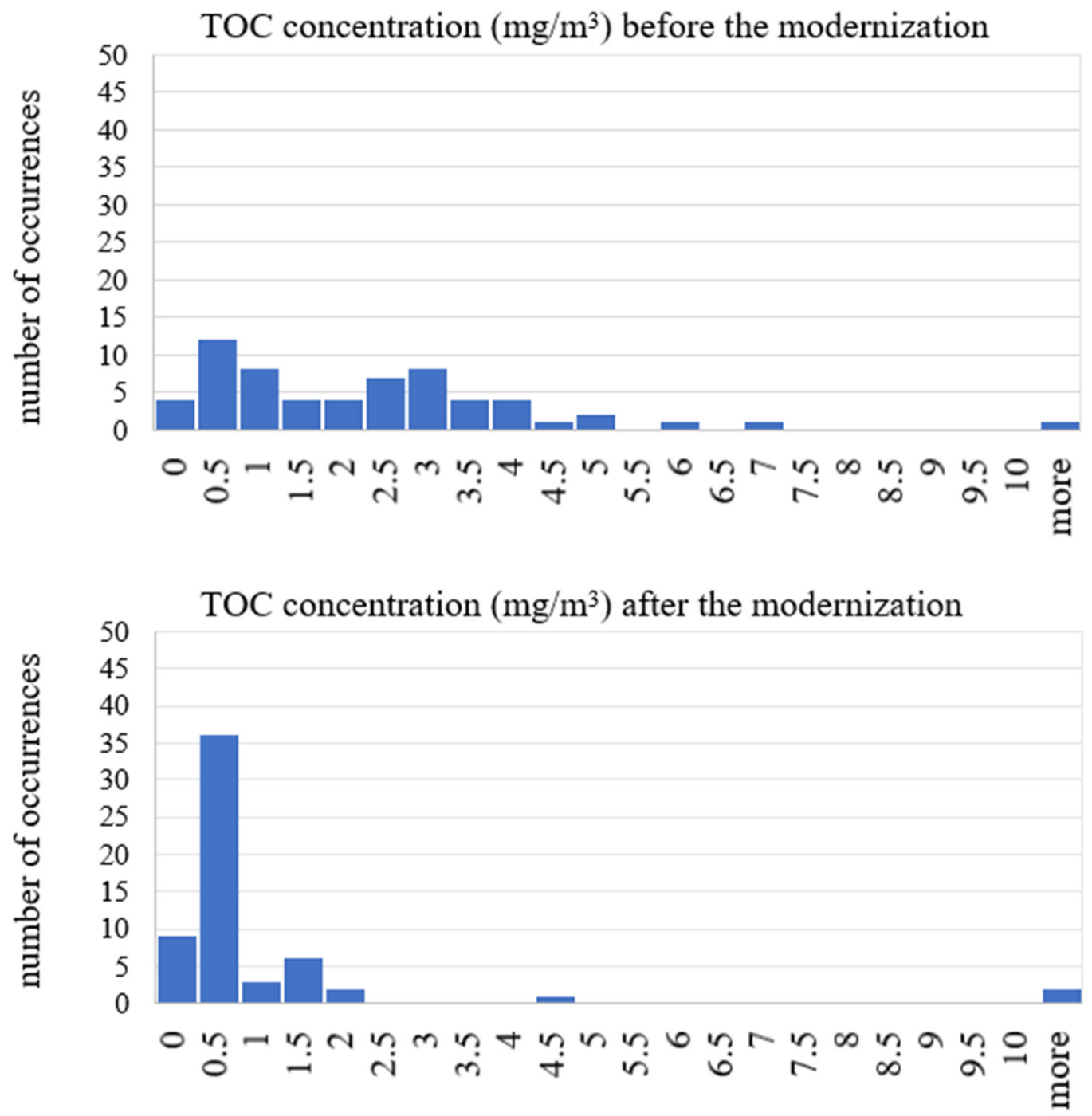

Figure 3. Comparison of average daily histograms of total organic compound (TOC) concentrations before and after Table 2. Comparison of average daily histograms of $\mathrm{CO}$ concentrations before and after the modernization. 
The results in Table 2 indicate that the modernization caused an expected increase in the average residence time of flue gases in the afterburner chamber (Figure 4), whereas the other significant parameters of afterburner chamber operation, i.e., the concentration of oxygen in flue gases and their temperature, remained unchanged.
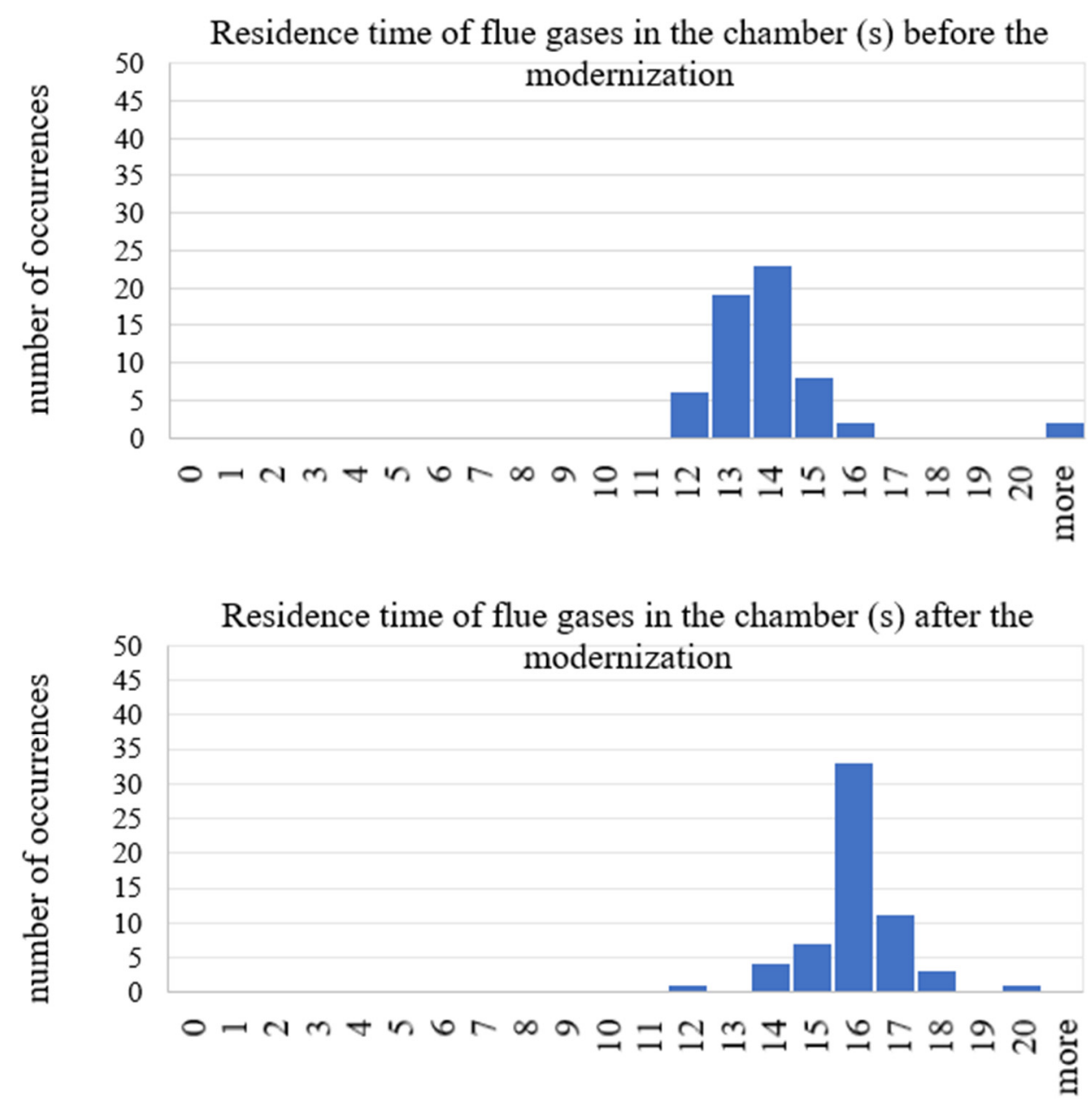

Figure 4. Comparison of average daily histograms of residence time of flue gases before and after the modernization.

For substances such as $\mathrm{SO}_{2}, \mathrm{HCl}$ and $\mathrm{HF}$, whose concentrations in the flue gases are reduced mainly by the secondary method, which involves sorbent dosing, their average concentration remained unchanged. On the other hand, after the redesign, an increase in the concentration of NOx (reduced by dosing urea) to $52.36 \mathrm{mg} / \mathrm{m}^{3}$ was observed. However, this is lower than the permissible value of $200 \mathrm{mg} / \mathrm{m}^{3}$. The analyses carried out earlier by the authors show, that in the described type of installation, the NOx concentration is closely correlated with the stream of additional air supplied to exhaust gases at a temperature of approximately $1100{ }^{\circ} \mathrm{C}$ in the afterburning chamber. The reason for the increase in concentration could be the extension of the flue-gas retention time under these conditions. Research on this issue is planned for the next planned reconstruction of other installations.

\section{Conclusions}

The data collected during the study described in this paper and the analysis results allowed us to evaluate the effects of the modernization of a thermal waste treatment plant. This modernization was intended to redesign the plant in order to reduce the risk of harmful substances being generated and emitted into the atmosphere, including volatile organic compounds and carbon monoxide. The redesign covered the afterburner chamber and involved installing an additional section. As a result of that change, the afterburner chamber 
volume increased from $64 \mathrm{~m}^{3}$ to $96 \mathrm{~m}^{3}$. In this case, the main factor contributing to the reduced emission was the more efficient afterburning of carbon compounds, achieved by increasing the residence time of flue gases and their circulation in the afterburner chamber.

Statistical comparisons of average technological parameters and the concentrations of harmful substances before and after the modernization indicate that the assumed changes were achieved. The average residence time of flue gases in the afterburner chamber was extended from 13.69 to $15.46 \mathrm{~s}$. At the same time, the average temperature and oxygen concentration of flue gases were not found to change significantly. As a consequence, the average daily TOC concentration decreased from $2.20 \mathrm{mg} / \mathrm{m}^{3}$ to $0.99 \mathrm{mg} / \mathrm{m}^{3}$. A substantial reduction in carbon monoxide emissions was also achieved, with the concentration lowered from $16.58 \mathrm{mg} / \mathrm{m}^{3}$ to $3.23 \mathrm{mg} / \mathrm{m}^{3}$. As expected, there was no change observed in the concentrations of $\mathrm{SO}_{2}, \mathrm{HC1}$ and $\mathrm{HF}$, i.e., compounds whose concentrations are reduced mainly by dosing sorbent. On the other hand, an increase in the NOx concentration to $52.36 \mathrm{mg} / \mathrm{m}^{3}$ was noted. However, this does not exceed the permissible value.

The results of the study indicate that the modernization (installation of an additional section in the afterburner chamber) improved the technological combustion process as assumed, contributing to the reduced emission of harmful substances.

Author Contributions: Conceptualization, J.B., P.S. and R.P.; methodology, J.B., P.S. and R.P.; data curation, J.B., P.S. and R.P.; formal analysis, J.B., P.S. and R.P.; writing-review and editing, J.B., P.S. and R.P. All authors have read and agreed to the published version of the manuscript.

Funding: This research received no external funding.

Institutional Review Board Statement: Not applicable.

Informed Consent Statement: Not applicable.

Data Availability Statement: Data available on request due to restrictions e.g., privacy.

Conflicts of Interest: The authors declare no conflict of interest.

\section{References}

1. European Union. Directive 2010/75/EU of the European Parliament and of the Council of 24 November 2010 on industrial emissions (integrated pollution prevention and control). Off. J. Eur. Union 2010, 334, 17-119. Available online: https:/ / eur-lex. europa.eu/legal-content/EN/TXT/?uri=celex\%3A32010L0075 (accessed on 14 May 2021).

2. European Union. COMMISSION IMPLEMENTING DECISION (EU) 2019/2010 of 12 November 2019 Establishing the Best Available Techniques (BAT) Conclusions, under Directive 2010/75/EU of the European Parliament and of the Council, for Waste Incineration (Notified under Document C(2019) 7987). Off. J. Eur. Union 2019, 312, 55-91. Available online: https: / / eur-lex.europa.eu/legal-content/EN/TXT/?uri=CELEX\%3A32019D2010 (accessed on 14 May 2021).

3. The Waste Incineration Directive 2000/76/EC. Available online: https://www.eea.europa.eu/themes/waste/links/wasteincineration-directive-2000-76-ec (accessed on 14 May 2021).

4. Zhang, G.; Huang, X.; Liao, W.; Kang, S.; Ren, M.; Jing Hai, J. Measurement of dioxin emissions from a small-scale waste incinerator in the absence of air pollution controls. Int. J. Environ. Res. Public Health 2019, 16, 1267. [CrossRef] [PubMed]

5. Lukáč, L.; Rimár, M.; Variny, M.; Kizek, J.; Lukáč, P.; Jablonský, G.; Janošovský, J.; Fedák, M. Experimental investigation of primary De-NOx methods application effects on NOx and CO emissions from a small-scale furnace. Processes 2020, 8, 940. [CrossRef]

6. Vehlow, J. Transformation of waste combustion facilities from major polluters to pollution sinks. In Waste to Energy Conversion Technology; Woodhead Publishing: Cambridge, UK, 2013; pp. 179-203. [CrossRef]

7. Huang, T.; Tang, Y.; Wang, S.; Zhang, C.; Ma, X. Volatilization characteristics and risk evaluation of heavy metals during the pyrolysis and combustion of rubber waste without or with molecular sieves. Ecotoxicol. Environ. Saf. 2020, 198, 110677. [CrossRef]

8. Poskrobko, S. Identification and stabilization of combusting animal waste with active participation of bone material-Emission of $\mathrm{SO}_{2}$ and $\mathrm{HCl}$. Fuel Process. Technol. 2013, 113, 20-27. [CrossRef]

9. Bujak, J.; Nakielska, M.; Sitarz, P. Analysis of meat and bone meal clean combustion conditions. J. Clean. Prod. 2021, 280, 124428. Available online: https://www.sciencedirect.com/science/article/abs/pii/S0959652620344723 (accessed on 14 May 2021). [CrossRef]

10. Bujak, J. New Insights into Waste Management-Meat Industry. Renew. Energy 2015, 83, 1174-1186. Available online: https: //www.sciencedirect.com/science/article/abs/pii/S0960148115300306 (accessed on 14 May 2021). [CrossRef]

11. Fedorowicz, E.M.; Miller, S.F.; Miller, B.G. Biomass gasification as a means of carcass and specified risk materials disposal and energy production in the beef rendering and meatpacking industries. Energy Fuels 2007, 21, 3225-3232. [CrossRef] 
12. Bujak, J. Thermal treatment of medical waste in a rotary kiln. J. Environ. Manag. 2015, 162, 139-147. Available online: https://www.sciencedirect.com/science/article/pii/S0301479715301936 (accessed on 14 May 2021). [CrossRef]

13. Bujak, J. Experimental study of the energy efficiency of an incinerator for medical waste. Appl. Energy 2009, 86, 2386-2393. Available online: https://www.sciencedirect.com/science/article/abs/pii/S0306261909000907 (accessed on 14 May 2021). [CrossRef]

14. Bujak, J. Production of waste energy and heat in hospital facilities. Energy 2015, 91, 350-362. [CrossRef]

15. Bujak, J.; Nakielska, M.; Sitarz, P. Multidimensional Analysis of Meat and Bone Meal (MBM) Incineration Process. Energies 2020, 13, 5787. [CrossRef]

16. Zimmer, C.; McKinley, D. New approaches to pollution prevention in the healthcare industry. J. Clean. Prod. 2008, 16, 734-742. Available online: https://www.sciencedirect.com/science/article/abs/pii/S0959652607000522 (accessed on 14 May 2021). [CrossRef]

17. Sang, Z.; Bo, Z.; Lv, X.; Weng, Y. Numerical investigations of the influencing factors on a rotary regenerator-type catalytic combustion reactor. Catalysts 2018, 8, 173. [CrossRef]

18. Cummins, E.J.; McDonnell, K.P.; Ward, S.M. Dispersion modelling and measurement of emissions from the co-combustion of meat and bone meal with peat in a fluidised bed. Bioresour. Technol. 2006, 97, 903-913. [CrossRef] [PubMed]

19. Fiedler, F. Process integration, modelling and optimisation for energy saving and pollution reduction. Appl. Therm. Eng. 2010, 30, 2270-2280. Available online: https://www.sciencedirect.com/science/article/abs/pii/S1359431110001936?via\%3Dihub (accessed on 14 May 2021). [CrossRef]

20. Wojtacha-Rychter, K.; Kucharski, P.; Smolinski, A. Conventional and Alternative Sources of Thermal Energy in the Production of Cement-An Impact on $\mathrm{CO}_{2}$ Emission. Energies 2021, 14, 1539. [CrossRef]

21. Wielgosiński, G. Pollutant Formation in Combustion Processes. Adv. Chem. Eng. 2012. Available online: https: //www.intechopen.com/books/advances-in-chemical-engineering/pollutants-formation-in-combustion-processes (accessed on 14 May 2021). [CrossRef]

22. Bujak, J.; Sitarz, P. Reduction of NOx and CO emissions through the optimization of incineration parameters in a rotary kiln. Environ. Prot. Eng. 2016, 42, 85-100. Available online: http://yadda.icm.edu.pl/baztech/element/bwmeta1.element.baztech-1f1 0cf4a-4d0d-42f6-a322-3788dd9a4d63 (accessed on 14 May 2021). [CrossRef]

23. Zanoelo, E.F.; Meleiro, L.A.C. A dynamic optimization procedure for non-catalytic nitric oxide reduction in waste incineration plants. Chem. Eng. 2007, 62, 6851-6864. Available online: https://www.cheric.org/research/tech/periodicals/view.php?seq=72 0140 (accessed on 14 May 2021). [CrossRef]

24. Continuous Exhaust Gas Monitoring System by Envag-Information Data. Available online: https://envag.com.pl/produkty/ systemy-monitoringu-emisji/ (accessed on 14 May 2021). 